\title{
CHARACTERIZATION OF CAST-IRON GRADIENT CASTINGS
}

\section{KARAKTERIZACIJA LITOŽELEZNEGA GRADIENTNEGA ULITKA}

\author{
Danijel Mitrović1, Primož Mrvar², Mitja Petrič² \\ ${ }^{1}$ Livar d.d., Slovenska cesta 43, 1295 Ivančna Gorica, Slovenia \\ ${ }^{2}$ Department of Materials and Metallurgy, Faculty of Natural Sciences and Engineering, University of Ljubljana, Aškerčeva 12 \\ 1000 Ljubljana, Slovenia \\ Danijel.Mitrovic@livar.si, Primoz.Mrvar@omm.ntf.uni-lj.si, Mitja.Petric@omm.ntf.uni-lj.si
}

Prejem rokopisa - received: 2014-07-07; sprejem za objavo - accepted for publication: 2014-12-08

doi:10.17222/mit.2014.102

This work deals with the topic of composed castings, also called gradient castings. The characterization of the microstructures and the subsequently monitored mechanical properties of the composite castings are discussed. The production technology is a combination of the horizontal centrifugal casting of alloyed white cast iron followed by an intermediate layer of flake grey cast iron and gravity casting of the core, which occurs in the third sequence. The core was made of spheroidal grey cast iron. The research was focused on the intermediate layer and a metallographic analysis of the intermediate layer, which is crucial for the defects and the lifetime of rolls.

The TCW program was used for the thermodynamic calculations of equilibrium phases in order to prove that the phases present in the microstructures were determined with light and scanning electron microscopy (SEM). Dilatometry in the solid state was done for all three layers to study the behavior of composed rolls during the thermal loading. The densities of microstructural constituents were calculated with the TAPP 2.2 software to explain the distribution of the phases in the intermediate layer Additionally, the linear hardness and the tensile strength at room and higher temperatures were measured.

Keywords: composite casting, centrifugal casting, gravity casting, intermediate layer, microstructure

V predstavljenem delu smo opredelili in karakterizirali mikrostrukturne sestavine ter spremljali mehanske lastnosti kompozitnega ulitka. Tehnologija izdelave je kombinacija horizontalnega in centrifugalnega litja legirane bele litine in kasneje sive litine (dve sekvenci) ter gravitacijskega litja jedra, ki se pojavi v tretji sekvenci. Jedro je izdelano iz sive litine s kroglastim grafitom. Raziskava je bila usmerjena na vmesno plast, ki je ulita iz sive litine z lamelnim grafitom in je ključnega pomena za pojav napak na valjih oziroma za trajnostno dobo valjev.

Uporabili smo naslednje preiskovalne metode: program TCW za termodinamični izračun faznih ravnotežnih faz v povezavi s svetlobno in elektronsko mikroskopijo, dilatometrijo v trdnem stanju za ugotavljanje razlik pri krčenju in širjenju vseh plasti, izračun gostot mikrostrukturnih komponent s programom TAPP 2.2 za določevanje razporeditve karbidov med strjevanjem, linearne meritve trdot ter natezne trdnosti pri sobni in povišanih temperaturah.

Ključne besede: kompozitni ulitek, centrifugalno litje, gravitacijsko litje, vmesna plast, mikrostruktura

\section{INTRODUCTION}

Centrifugal pouring technology is a casting process, where metal can be poured and solidified in a rotating permanent mold under the influence of the centrifugal force. ${ }^{1}$ The direction of solidification in the centrifugal process differs from that in the sand casting. Due to a rapid transfer of heat to the permanent mold, crystallization starts on the outer surface of the casting and progresses towards the inside. The result is a fine-grained surface crust. Further solidification towards the interior takes place with the growth of dendrite crystals. ${ }^{2}$ Dendrites can have an equiaxed or columnar shape, depending on the thermal gradient during the solidification. ${ }^{3}$

A cast roll can be produced as a gradient casting composed of a hard steel shell as the working layer and a tough core. The microstructure of the working layer of a roll after the solidification depends on the chemical composition of the alloy. The main microstructural constituent is austenite $(\gamma)$ that solidified in the form of dendrites, followed by a eutectic, which consists of austenite and carbides. ${ }^{4}$ The type of the carbides is determined by the chemical composition. Usually the alloys for rolls are alloyed with $\mathrm{Cr}, \mathrm{Ni}, \mathrm{W}, \mathrm{Mo}$ and V.,6 For a chromium-white-cast-iron working layer, it is desirable to have as little as possible of the retained austenite in the matrix and no pearlite phase in the microstructure.

In the as-cast state, the matrix contains a substantial proportion of the residual austenite (30-60\%) that has to decompose with a single or multistage heat treatment in order to achieve the required microstructure, containing small and evenly distributed $\mathrm{M}_{23} \mathrm{C}_{6}$ type carbides in the $\alpha$-metallic matrix. ${ }^{7}$ Due to their high hardness and uniform distribution in the matrix, secondary carbides are of a great importance for the wear resistance. The target mechanical properties are obtained with the heat treatment, where a casting is heated to the austenitizing temperature and control cooled to room temperature. Such a treatment allows a good control over the segregation of the secondary carbides in a temperature range from $800{ }^{\circ} \mathrm{C}$ to $1050{ }^{\circ} \mathrm{C}$.

Rolls can be produced by forging or by casting. Cast rolls are often produced as gradient castings made of more than one material. The outer layer of a casting, or 
Table 1: Chemical analysis of a gradient casting ( $w / \%)$

Tabela 1: Kemijska analiza gradientnega ulitka $(w / \%)$

\begin{tabular}{|c|c|c|c|c|c|c|c|c|c|c|c|c|c|c|c|c|c|c|c|c|c|c|c|c|c|c|}
\hline & $\mathrm{C}$ & $\mathrm{Si}$ & $\mathrm{Mn}$ & $\mathrm{P}$ & $\mathrm{S}$ & $\mathrm{Cr}$ & $\mathrm{Ni}$ & $\mathrm{Mo}$ & $\mathrm{Mg}$ & $\mathrm{Cu}$ & $\mathrm{Sn}$ & $\mathrm{Al}$ & $\mathrm{V}$ & $\mathrm{Ti}$ & $\mathrm{W}$ & $\mathrm{Co}$ & $\mathrm{Fe}$ \\
\hline Working layer & 2.799 & 0.703 & 0.965 & 0.030 & 0.037 & 16.681 & 1.433 & 1.154 & 0.003 & 0.081 & 0.000 & 0.0000 & 0.296 & 0.000 & 0.000 & 0.000 & 75.818 \\
\hline Intermediate layer & 3.118 & 1.034 & 0.342 & 0.026 & 0.010 & 0.129 & 0.247 & 0.029 & 0.000 & 0.039 & 0.005 & 0.0013 & 0.012 & 0.006 & 0.009 & 0.018 & 94.965 \\
\hline Core & 3.002 & 2.734 & 0.366 & 0.031 & 0.007 & 0.131 & 0.247 & 0.029 & 0.099 & 0.039 & 0.007 & 0.0229 & 0.013 & 0.007 & 0.009 & 0.017 & 93.198 \\
\hline
\end{tabular}

the working layer, made with horizontal centrifugal casting, is followed by a centrifugally cast intermediate layer and the final layer is the gravity-cast core made of spheroidal cast iron. The working layer is often made of chromium white cast iron to achieve the hardness and wear resistance. The intermediate layer is a sort of grey cast iron, creating a good bond between the working layer and the core; and the core is made of nodular cast iron to obtain ductility during the casting. ${ }^{8,9}$ The bonding between the working layer and the core is important since poor bonding can cause bond-related spalls. ${ }^{10}$

The aim of the paper is to describe the formation and types of the carbides in the intermediate layer and the bonding between the working layer and the core. The bonding is crucial for the defects and lifetime of a roll. Also, the mechanical properties across the cross-section are determined and the mechanism of a possible crack formation is explained.

\section{EXPERIMENTAL WORK}

The analyses were carried out on the samples taken from the working layer, the intermediate layer and the core. Light microscopy, scanning electron microscopy (SEM) with an EDS analysis, tensile tests at various temperatures, hardness measurements and a dilatometric analysis were carried out. The densities of the solidified phases were calculated with the TAPP 2.2 program and

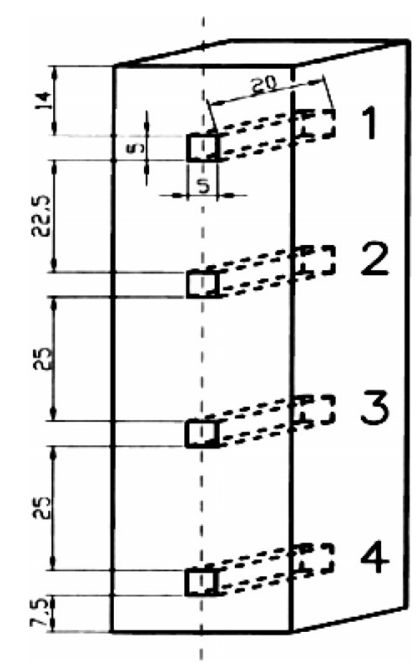

Figure 1: Presentation of the sampling for a dilatometric analysis (sample 1 - working layer, sample 2 - working layer, sample 3 - intermediate layer, sample 4 - core)

Slika 1: Predstavitev vzorčenja za dilatometrsko analizo (vzorec 1 delovna plast, vzorec 2 - delovna plast, vzorec 3 - vmesna plast, vzorec 4 - jedro) the thermodynamic-phase equilibrium calculations were performed with the Thermo-Calc software.

The analyses were carried out on the samples taken from the working layer, the intermediate layer and the core, at a depth of approximately $80 \mathrm{~mm}$ into the roll. Metallographic samples were taken from all three layers and metallographically prepared by grinding, polishing and etching with $2 \%$ Nital. The samples for the tensile tests were taken from the working layer in the longitudinal direction of a roll. The test pieces had round cross-sections with a diameter of $10 \mathrm{~mm}$. The test pieces for dilatometric analyses were taken from all three layers of a roll as indicated in Figure 1. The test pieces had dimensions of $5 \mathrm{~mm} \times 5 \mathrm{~mm} \times 20 \mathrm{~mm}$. The dilatometric analyses were carried out at a heating rate of $20 \mathrm{~K} / \mathrm{s}$, up to $1100{ }^{\circ} \mathrm{C}$, at which the samples were held for $5 \mathrm{~min}$ and then cooled at the same rate to $400{ }^{\circ} \mathrm{C}$.

The microstructure was analyzed with light microscopy using an Olympus BX61 microscope and with scanning electron microscopy using a JEOL JSM-5600 electron microscope equipped with EDS. The tensile tests at elevated temperatures were carried out according to the EN ISO 6892 standard, using an Instron 1255 machine at room temperature and at $(300,400,500,600$, 700 and 800) ${ }^{\circ} \mathrm{C}$. Rockwell-hardness measurements were performed using an Instron Tukon $2100 \mathrm{~B}$ machine and a dilatometric analysis performed by a BÄHR DIL 801 instrument, on the area from the surface of a roll up to 80 $\mathrm{mm}$ into the depth of the roll, every $2-5 \mathrm{~mm}$. The densities of the solidified microstructural phases were calculated with the TAPP 2.2 program and the thermodynamic-phase equilibrium calculations were performed with the Thermo-Calc software.

Chemical compositions of all three layers are presented in Table 1.

\section{RESULTS AND DISCUSSION}

Figure 2 presents the boundary area of the working layer, the intermediate layer and the core. The microstructure of the working layer consists of austenite and carbides since the alloy is rich in chromium and molybdenum. The intermediate layer, which merges with the core, is highly rich in $\mathrm{M}_{7} \mathrm{C}_{3}$ carbides. During the first stage of the solidification of the intermediate layer, the formation of primary austenite crystals occurs in the liquid melt, which, due to the centrifugal force and the density higher than the rest of the melt, starts to move in the direction of the working layer. The melt of the intermediate layer re-melts and merges with a thin layer 


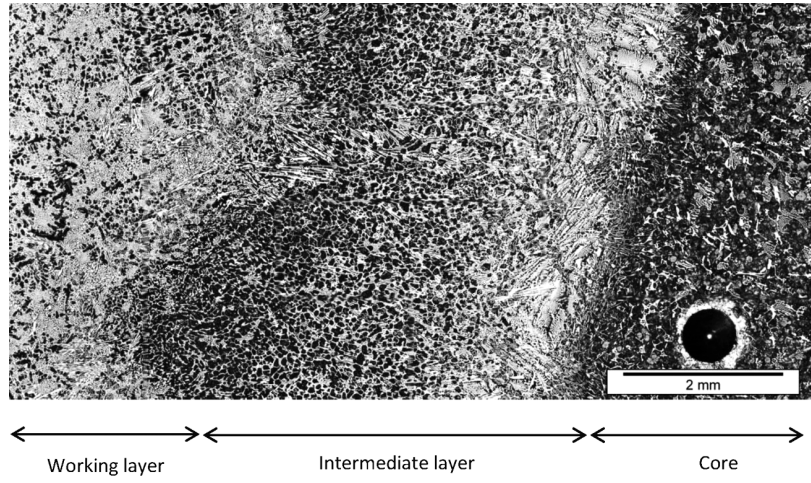

Figure 2: Macrostructure of the working layer, the intermediate layer and the core

Slika 2: Makroposnetek delovne plasti, vmesne plasti in jedra

of the working layer and some carbide-promoting elements, especially chromium, dissolve in the intermediate melt, causing the formation of carbide sand due to a lower density in comparison with $\gamma$, deposited at the interface of the intermediate layer and the core. A large amount of carbides can be clearly seen on Figure 2. A sufficient solidification interval and lower cooling rates cause an intermediate layer stratified in this way, which is an undesirable microstructure. The carbides that are not evenly dispersed in the metal matrix represent the brittle layer of the casting.

Figure 3 shows the isopleth phase diagram of the working-layer material. The solidification starts with the solidification of austenite, followed by a eutectic reaction with the solidification of the $\mathrm{M}_{7} \mathrm{C}_{3}$ type carbides between $1260{ }^{\circ} \mathrm{C}$ and $1230{ }^{\circ} \mathrm{C}$. The precipitation of the $\mathrm{M}_{23} \mathrm{C}_{6}$ type carbides takes place at $820{ }^{\circ} \mathrm{C}$.

Figure 4a shows a SEM microphotograph of the working layer, where the large particles are the carbides that solidified during the eutectic reactions. The EDS

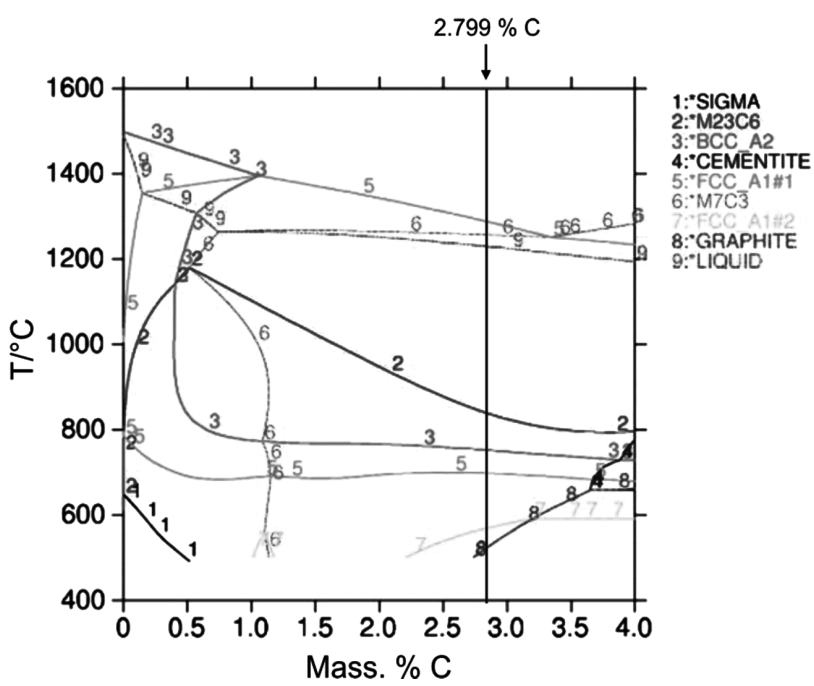

Figure 3: Isopleth phase diagram of the working layer with marked chemical composition

Slika 3: Izopletni fazni diagram delovne plasti z označeno kemijsko sestavo analysis shows that this phase includes the $\mathrm{M}_{7} \mathrm{C}_{3}$ type carbides. Smaller particles in the matrix are the $\mathrm{M}_{23} \mathrm{C}_{6}$ type carbides that precipitated in the solid state from the solid solution of austenite. According to Vitry et al. ${ }^{6}$ the $\mathrm{M}_{7} \mathrm{C}_{3}$ and $\mathrm{M}_{23} \mathrm{C}_{6}$ type carbides should be chromium carbides, but from the EDS analyses it is clear that these carbides are mainly chromium and iron carbides with some small amounts of $\mathrm{V}$ and Mo. The types of carbides are the same as predicted by the thermodynamic calculations from Figure 3. It is clear that practically the whole austenite was transformed into martensite during the heat treatment. The intermediate layer also contains carbides, determined with the EDS analysis to be of the $\mathrm{M}_{7} \mathrm{C}_{3}$ type, as seen on Figure $\mathbf{4 b}$. There is a small amount of smaller particles of secondary carbides $\mathrm{M}_{23} \mathrm{C}_{6}$ distributed

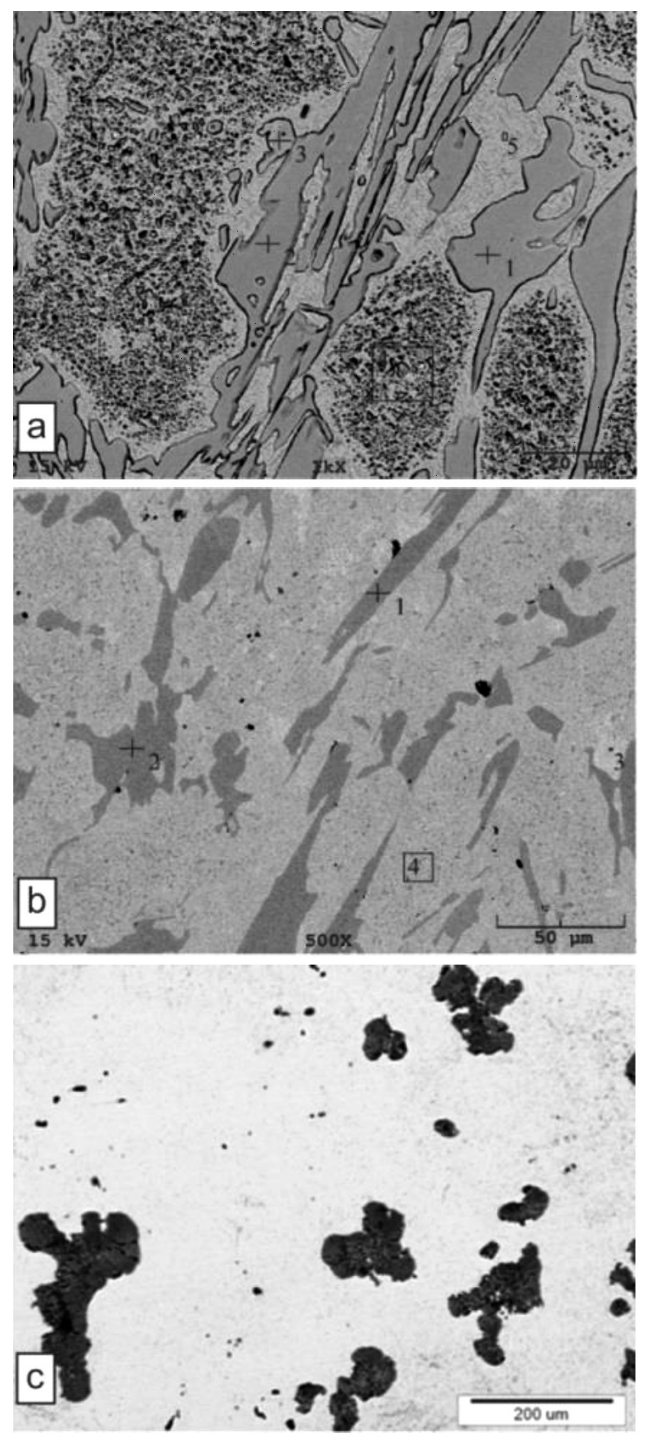

Figure 4: Microstructures of all three layers: a) SEM microphotograph of working layer, b) SEM microphotograph of intermediate layer and c) light microphotograph of core

Slika 4: Mikrostrukture vseh treh plasti: a) SEM-mikroskopija delovne plasti, b) SEM-mikroskopija vmesne plasti ter c) svetlobna mikroskopija jedra 

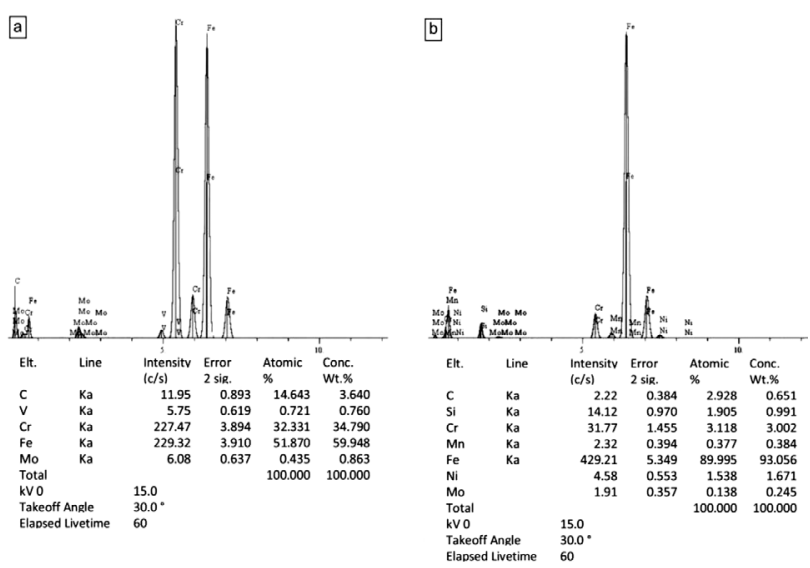

c
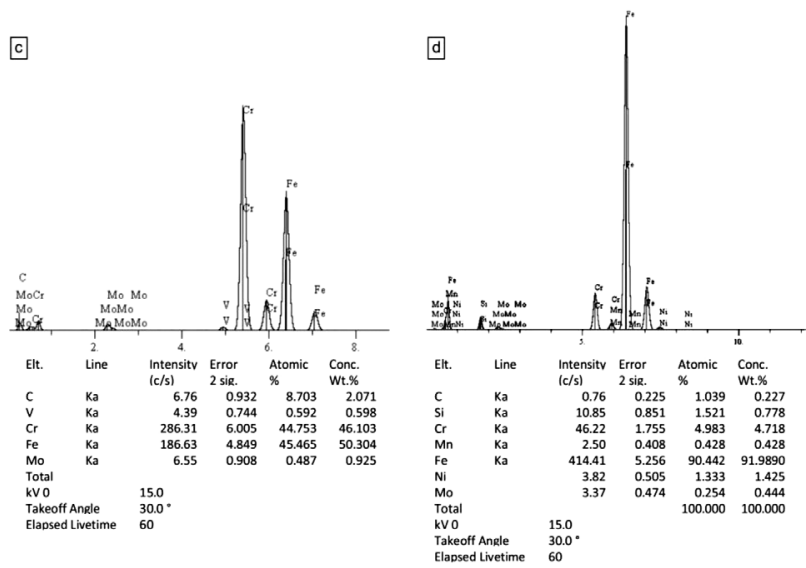

Figure 5: EDS spectrums of phases: a) $\mathrm{M}_{7} \mathrm{C}_{3}$ carbide, spot 1 on Figure $4 \mathbf{b}, b$ ) martensite, spot 3 on Figure $4 \mathbf{b}$, c) carbides $\mathrm{M}_{23} \mathrm{C}_{6}$, spot 6 on Figure $4 a$ and d) martensite with carbide $\mathrm{M}_{23} \mathrm{C}_{6}$, spot 4 on Figure 4b

Slika 5: EDS-spektri faz: a) $\mathrm{M}_{7} \mathrm{C}_{3}$ karbida, območje 1 na sliki $\mathbf{4 b}$, b) martenzit, območje 3 na sliki $4 \mathbf{b}, c)$ karbid $\mathrm{M}_{23} \mathrm{C}_{6}$, območje 6 na sliki 4a ter d) martenzit s karbidi $\mathrm{M}_{23} \mathrm{C}_{6}$, območje 3 na sliki $\mathbf{4 b}$

in the martensite matrix; this amount is much lower since the concentration of the carbide-promoting elements is much lower than in the working layer. Figure $\mathbf{4 c}$ shows a light microphotograph of the core in the polished state, where graphite can be seen in the iron matrix. Graphite is expected to be in the nodule-like form, but here this is not the case, probably due to an insufficient Mg-treatment and a burn-off of $\mathrm{Mg}$ during the long solidification time of the core.

Figure 5 presents EDS spectrums of the analyzed microstructural constituents marked on Figures $\mathbf{4 a}$ and $\mathbf{4 b}$.

With the help of the TAPP 2.2 program, the densities of the eutectic $\mathrm{M}_{7} \mathrm{C}_{3}$ carbides and austenite at the reference solidification temperature were calculated. The density of carbides $\mathrm{M}_{7} \mathrm{C}_{3}$ at the temperature of precipitation is $6.738 \mathrm{~kg} / \mathrm{dm}^{3}$; austenite has a density of a 6.99 $\mathrm{kg} / \mathrm{dm}^{3}$ at the temperature of precipitation. Given the relative differences in the density between the austenite, the carbides and the melt in the solidification stage of the intermediate layer, it seems that the stratification of both microstructural ingredients takes place. In the first stage, austenite dendrites appear and they are pushed by the centrifugal forces and a higher density in the direction towards the working layer. When the temperature of the remaining melt falls within the scope of the eutectic solidification, leading to the development of a nucleation and growth of the carbides they are pushed in the direction of the interface between the intermediate layer and the core since the carbides have a lower density than the austenite. The difference in the density between the austenite and carbides is only $0.3 \mathrm{~kg} / \mathrm{dm}^{3}$, but it is much more significant at a centrifugal force of $120 \mathrm{G}$ leading to an inhomogeneous microstructure development.

Rockwell-hardness measurements were carried out in the area between the surface of the casting and the depth of $80 \mathrm{~mm}$. Figure 6a presents the hardness of the working layer, which is around 61 HRC up to the depth of $60 \mathrm{~mm}$ where the intermediate layer starts. In this layer the hardness starts to descend and continues to descend in the core too where it drops to only $32 \mathrm{HRC}$.

The tensile tests (Figure 6b) of the working layer at different temperatures show that the tensile strength is lowered by about $10 \%$ at $400{ }^{\circ} \mathrm{C}$ and, at higher temperatures, it declines even faster and reaches only $200 \mathrm{MPa}$ at $700{ }^{\circ} \mathrm{C}$. This means that the working layer has a tendency to from cracks during the cooling of the casting,
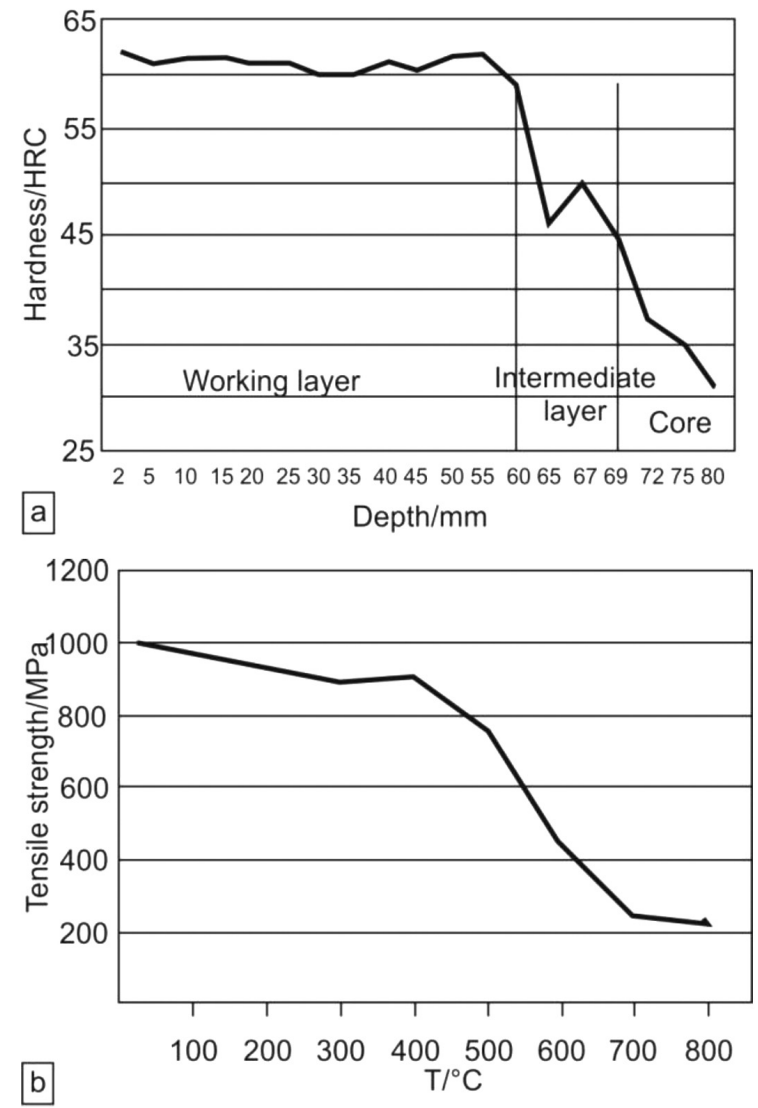

Figure 6: Mechanical properties: a) hardness and b) tensile strength at different temperatures

Slika 6: Mehanske lastnosti: a) trdota ter b) natezna trdnost pri različnih temperaturah 


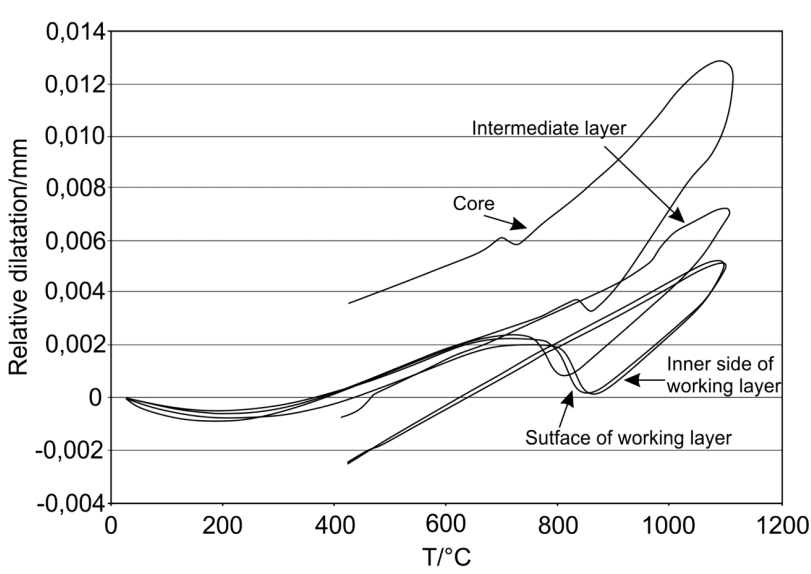

Figure 7: Dilatation curves of the samples at different layers Slika 7: Dilatacijske krivulje vzorcev različnih plasti

since the core has a much higher temperature, causing the tensile stresses in the working layer.

Figure 7 presents a dilatometric analysis of four samples, two from the working layer, one from the intermediate layer and one from the core. We can see that the working layer has the lowest dilatation in the temperature range from room temperature to up to $1100{ }^{\circ} \mathrm{C}$. The intermediate layer has a slightly higher dilatation at the highest temperature, but the core has the highest dilatation. These differences in dilatation cause high internal stresses during the cooling of the gradient casting. It is clear that when the casting is being cooled from the surface side, the working layer is shrinking faster than the core, which causes the tensile stresses in the working layer and these might lead to a crack formation. A similar situation takes place during the heat treatment, where the whole casting is heated to the austenitizing temperature and the core expands more than the working layer, causing tensile stresses again. On Figure 7 we can see that the quantitative difference in dilatation of the samples is $0.055 \mathrm{~mm}$ at $1000{ }^{\circ} \mathrm{C}$ which is not an insignificant value.

\section{CONCLUSIONS}

The solidification of three different layers was determined in the present work. It is clear that the intermediate layer re-melts the working layer and some carbide-promoting elements dissolve in the intermediate liquid layer, causing the formation of the $\mathrm{M}_{7} \mathrm{C}_{3}$ type carbides during the solidification. The working layer consists also of secondary carbides of the $\mathrm{M}_{23} \mathrm{C}_{6}$ type. This finding is confirmed by a thermodynamic calculation, which shows that the solidification of austenite is followed by the solidification of the $\mathrm{M}_{7} \mathrm{C}_{3}$ type carbide eutectic and a further precipitation of the $\mathrm{M}_{23} \mathrm{C}_{6}$ carbides.

The $\mathrm{M}_{7} \mathrm{C}_{3}$ type carbides have a lower density than austenite; as a result, at a slow solidification rate of the intermediate layer, the formed carbides are pushed by high centrifugal forces into the inner part of the layer. In this way, an inhomogeneous microstructure is obtained, which is inappropriate for the lifetime of the roll.

The tensile strength of the working layer is not changed until the temperature reaches $500{ }^{\circ} \mathrm{C}$, and then it is rapidly lowered, which can lead to a casting failure if such working temperatures occur also during the lifetime.

The hardness of the gradient-casting cross-section is on a decrease towards the intermediate layer, which is the result of a lower concentration of primary and secondary carbides.

A dilatometric analysis showed big differences in the linear thermal-expansion coefficients of different layers. The difference in dilatation between the working layer and the core is $0.055 \mathrm{~mm}$ at $1000{ }^{\circ} \mathrm{C}$. Such differences in the contraction or expansion during the cooling and heating of the solidification process, heat treatment or during the working cycles of a roll can cause stresses that may exceed the ultimate tensile strength of the working layer, initiating a crack that may result in a roll failure.

\section{REFERENCES}

${ }^{1}$ Manual for centrifugal casting of rolls, Valji Štore, Valji Štore, d. o. o., Štore 1986

${ }^{2}$ J. P. Breyer, G. Walmag, Metallurgy of High Chromium-Molybdenum White Iron and Steel Rolls, Rolls for the Metalworking Industries, Iron and Steel Society, Warendale 2002, 29-40

${ }^{3}$ W. Wolczynski, E. Guzik, W. Wajda, D. Jedrzejczyk, B. Kania, M. Kostrzewa, CET in Solidifying Roll - Thermal Gradient Field Analysis, Archives of Metallurgy and Materials, 57 (2012) 1, 105-117, doi:10.2478/v10172-011-0159-9

${ }^{4}$ M. Yamamoto, I. Narita, H. Miyahara, Fractal Analysis of Solidification Microstructure of High Carbon High Alloy Cast Roll Manufactured by Centrifugal Casting, Tetsu To Hagane - Journal of the Iron and Steel Institute of Japan, 99 (2013) 2, 72-79, doi:10.2355/ tetsutohagane.99.72

${ }^{5}$ M. Kang, Y. Suh, Y. J. Oh, Y. K. Lee, The effects of vanadium on the microstructure and wear resistance of centrifugally cast Ni-hard rolls, Journal of Alloys and Compounds, 609 (2014), 25-32, doi:10.1016/ j.jallcom.2014.04.184

${ }^{6}$ V. Vitry, S. Nardone, J. P. Breyer, M. Sinnaeve, F. Delaunois, Microstructure of two centrifugal cast high speed steels for hot strip mills applications, Materials and Design, 34 (2012), 372-378, doi:10.1016/j.matdes.2011.07.041

${ }^{7}$ F. Gologranc, Preoblikovanje, Vol. 1, Fakulteta za strojništvo, Ljubljana 1991

${ }^{8}$ G. Rivera, P. R. Calvillo, R. Boeri, Y. Houbaert, J. Sikora, Examination of the solidification macrostructure of spheroidal and flake graphite cast irons using DAAS and ESBD, Materials Characterization, 59 (2008) 9, 1342-1348, doi:10.1016/j.matchar.2007.11.009

${ }^{9}$ Y. Bai, Y. Luan, N. Song, X. Kang, D. Li, Y. Li, Chemical Compositions, Microstructure and Mechanical Properties of Roll Core used Ductile Iron in Centrifugal Casting Composite Rolls, Journal of Materials Science and Technology, 28 (2012) 9, 853-858, doi:10.1016/S1005-0302(12)60142-X

${ }^{10}$ Roll Failures Manual, Hot Mill Cast Work Rolls, $1^{\text {st }}$ ed., CAEF - The European Foundry Association - Roll Section, Duesseldorf 2002, p. 10 